\title{
p53 and Fas ligand are required for psoralen and UVA-induced apoptosis in mouse epidermal cells
}

\author{
AB Santamaria1, DW Davis², DX Nghiem', DJ McConkey², \\ SE Ullrich ${ }^{1}$, M Kapoor $^{3}$, G Lozano ${ }^{3}$ and HN Ananthaswamy ${ }^{*, 1}$ \\ ${ }^{1}$ Department of Immunology, The University of Texas M.D. Anderson Cancer \\ Center, Houston, Texas 77030, USA \\ 2 Department of Cancer Biology, The University of Texas M.D. Anderson Cancer \\ Center, Houston, Texas 77030, USA \\ 3 Department of Molecular Genetics, The University of Texas M.D. Anderson \\ Cancer Center, Houston, Texas 77030, USA \\ * Corresponding author: HN Ananthaswamy, The University of Texas M.D. \\ Anderson Cancer Center, 1515 Holcombe Blvd., Houston, Texas 77030, USA. \\ Tel: (713) 792 8595; Fax: (713) 794-1322; \\ E-mail: hanantha@mdanderson.org
}

Received 20.7.01; revised 20.11.01; accepted 29.11.01

Edited by DR Green

\begin{abstract}
A combination of 8-methoxypsoralen (8-MOP) and ultraviolet$A(U V A)$ radiation (320-400 $\mathrm{nm}$ ) (PUVA) is widely used in the treatment of psoriasis and other skin diseases. PUVA is highly effective in eliminating hyperproliferative cells in the epidermis, but its mechanism of action has not been fully elucidated. In this study, we used immortalized JB6 mouse epidermal cells, $p 53^{-I-}$, and Fas ligand deficient (gld) mice to investigate the molecular mechanism by which PUVA induces cell death. The results indicate that PUVA treatment induces apoptosis in JB6 cells. In addition, PUVA treatment of JB6 cells results in p53 stabilization, phosphorylation, and nuclear localization as well as induction of $\mathrm{p} 21^{\text {Waf/Cip1 }}$ and caspase-3 activity. In vivo studies reveal that PUVA treatment induces significantly less apoptosis in the epidermis of $p 53^{-1-}$ mice compared to $\mathrm{p}^{3}{ }^{+++}$mice. Furthermore, FasL-deficient ( $\mathrm{gld}$ ) mice are completely resistant to PUVA-induced apoptosis compared to wild-type mice. These results indicate that PUVA treatment induces apoptosis in mouse epidermal cells in vitro and in vivo and that p53 and Fas/Fas ligand interactions are required for this process, at least in vivo. This implies that similar mechanisms may be involved in the elimination of psoriatic keratinocytes from human skin following PUVA therapy.

Cell Death and Differentiation (2002) 9, 549-560. DOI: 10.1038/ sj/cdd/4401007
\end{abstract}

Keywords: PUVA therapy; psoriasis; programmed cell death; keratinocytes

Abbreviations: 8-MOP, 8-methoxypsoralen; PUVA, psoralen and UVA radiation; CTCL, cutaneous T-cell lymphoma; FasL, Fas Ligand; MTT, 3-(4-5-dimethylthiazol-2-yl)-2,5-diphenyltetrazolium bromide; FACS, fluorescence activated cell sorter; TEM, transmis- sion electron microscopy; TUNEL, terminal deoxyribonucleotidyl transferase (TdT)-mediated dUTP nick end labeling; FITC, fluorescein isothiocyanate; PI, propidium iodide; DMSO, dimethylsulfoxide; PEITC, phenethyl isothiocyanate; FADD, Fas-associated death domain.

\section{Introduction}

The human skin diseases, psoriasis, cutaneous T-cell lymphoma (CTCL), and vitiligo are commonly treated with a combination of psoralens and UVA radiation, commonly referred to as 'PUVA' therapy. ${ }^{1-3}$ 8-Methoxypsoralen (8$M O P$ ) is a naturally occurring inert chemical that can be photoactivated by UVA to become a potent photosensitizing agent. It is a tricyclic aromatic compound with a planar structure that helps it intercalate between nucleic acid base pairs. UVA activates the intercalated complex, resulting in the formation of photoadducts with pyrimidines in cellular DNA. ${ }^{4-7}$ The psoralen monoadducts formed in the DNA can further react photochemically with a pyrimidine base on the complementary strand of the DNA, thus leading to crosslinks that are believed to be the primary cause of PUVA-induced cell killing. ${ }^{7,8}$ Even though PUVA treatment is known to be mutagenic and carcinogenic, ${ }^{9-13}$ it remains a treatment of choice for psoriasis and other skin disorders because its benefits far outweigh its risks.

Although many aspects of PUVA therapy have been studied extensively, the molecular mechanism by which it kills cells has not been fully elucidated. Some studies have shown that PUVA induces apoptosis in human lymphocytes and CTCL cell lines, ${ }^{14-20}$ but the precise pathways and molecules involved remain largely unidentified. In fact, except for one study with rat skin, in which induction of sunburn cells and DNA fragmentation were observed after PUVA treatment, in vitro or in vivo studies have not been performed to evaluate the mechanisms of cell death in epidermal cells, which are the primary targets of treatment for psoriasis. ${ }^{21}$

Many studies have shown that the p53 protein is influential in mediating apoptosis. The p53 phosphoprotein acts as the guardian of the genome by halting the cell cycle to allow repair or, if repair is not possible, promoting cell death by apoptosis. ${ }^{22,23}$ DNA-damaging agents such as UV and ionizing radiation induce high levels of $\mathrm{p} 53,{ }^{24-27}$ which in turn activate the transcription of downstream genes responsible for cell-cycle arrest at the $G_{1}-S$ transition. ${ }^{28}$ In particular, p53 can activate p21 Waf1/Cip1 , which binds to and inactivates the cyclin-dependent kinases required for cellcycle progression ${ }^{29}$ and may activate genes involved in DNA repair while the cell cycle is arrested. ${ }^{30}$ Alternatively, if the damage is irreparable, p53 may activate genes involved in apoptosis. ${ }^{31}$ Most DNA-damaging agents induce apoptosis via a p53-mediated pathway, although apoptosis may be 
induced in a p53-independent manner as well. ${ }^{32-34}$ Studies with $\mathrm{p} 53^{-1-}$ mice have shown that $\mathrm{p} 53$ is required for the elimination of DNA-damaged skin cells through apoptosis. ${ }^{35}$

UV irradiation induces the expression of both Fas (APO$1 / \mathrm{CD} 95$ ) and its ligand (FasL) in keratinocytes at mRNA and protein levels. ${ }^{36}$ Although previous studies have reported that PUVA treatment induces p53 expression in epidermal cells ${ }^{37}$ and in the skin of individuals with psoriasis, $^{38}$ it is unknown whether p53 and Fas/FasL interactions are in fact required for PUVA-induced apoptosis. In this study, we used in vitro and in vivo approaches using JB6 mouse epidermal cells and $\mathrm{p} 53^{-1-}$ and fasL $^{-1-}$ (gld) mice to answer these questions.

\section{Results}

\section{PUVA treatment decreases viability of JB6 cells}

After several preliminary dose-response experiments using the MTT viability assay, $10 \mu \mathrm{g} / \mathrm{ml} 8-\mathrm{MOP}$ and $20 \mathrm{~kJ} / \mathrm{m}^{2} \mathrm{UVA}$ were selected for further studies because this combination caused cell death in a time-dependent manner, whereas treatment with 8-MOP or UVA alone did not. To quantify PUVA-induced cell death in JB6 epidermal cells, viable cell density was determined using the trypan blue dye exclusion assay. As shown in Figure 1, PUVA treatment caused apparent growth arrest at $24 \mathrm{~h}$, followed by cell death at 48 and $72 \mathrm{~h}$. The number of ethanol-treated cells increased by 180,235 , and $320 \%$ at 24,48 , and $72 \mathrm{~h}$ after treatment, respectively, while the number of PUVA-treated cells decreased to 90,30 , and $18 \%$ of viable cells at time 0 . These results indicate that the population of cells in the control group approximately doubled every $24 \mathrm{~h}$. However, the population of cells in the PUVA-treated group remained approximately the same at $24 \mathrm{~h}$, and decreased greatly at 48 and $72 \mathrm{~h}$ after treatment, suggesting initial growth arrest followed by cell death. JB6 cells treated with 8-MOP or UVA alone did not

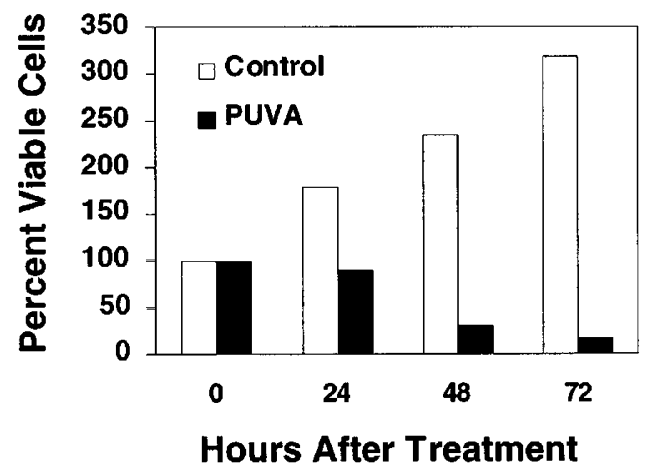

Figure 1 PUVA treatment causes initial growth arrest followed by cell death in JB6 cells. The percentage of viable cells at 24,48 , and $72 \mathrm{~h}$ after treatment, relative to the number of viable cells at time 0 (just prior to treatment) are shown. The number of ethanol-treated cells increased by 180, 235 and $320 \%$, while the number of PUVA-treated cells decreased to 90,30 , and $18 \%$ of viable cells at time 0 , at 24,48 , and $72 \mathrm{~h}$ after treatment, respectively. However, JB6 cells treated with 8-MOP or UVA alone did not undergo cel death and the percentage of viable cells at $0-72 \mathrm{~h}$ after treatment was comparable to cells treated with ethanol at $0-72 \mathrm{~h}$ time points, respectively (data not shown) undergo cell death and the percentage of viable cells at 0 $72 \mathrm{~h}$ after treatment was comparable to cells treated with ethanol at $0-72 \mathrm{~h}$ time points, respectively (data not shown).

\section{PUVA treatment induces apoptosis in JB6 cells}

Apoptotis results in characteristic morphological changes, including nuclear condensation, cytoplasmic vesiculation, and the formation of membrane-bound bodies that can be phagocytosed by other cells. ${ }^{39}$ These changes can be observed by fluorescence microscopy or transmission electron microscopy (TEM). ${ }^{40}$ TEM analysis of PUVA-treated cells revealed morphological characteristics of apoptosis such as cytoplasmic vesiculation, condensation, and margination of the nuclear chromatin $24 \mathrm{~h}$ after treatment (Figure $2 \mathrm{~A}$ ) and had formed apoptotic bodies 48 to $72 \mathrm{~h}$ after treatment (data not shown).

In addition to exhibiting specific morphological changes, cells that die by apoptosis undergo a variety of characteristic biochemical changes. ${ }^{41} \mathrm{~A}$ hallmark of apoptosis is the formation of 180 - to 200 -bp segments that are a result of double-stranded DNA fragmentation at the linker regions between nucleosomes. As shown in Figure 2B, PUVA treatment resulted in the appearance of ladders at 48 and $72 \mathrm{~h}$ after treatment, indicating that the DNA was fragmented. No evidence of ladder formation was seen in cells treated with 8-MOP or UVA at any time point (data not shown).

We also performed terminal deoxyribonucleotidyl transferase (TdT)-mediated dUTP nick end labeling (TUNEL) to quantify apoptotic JB6 cells at different times after PUVA.
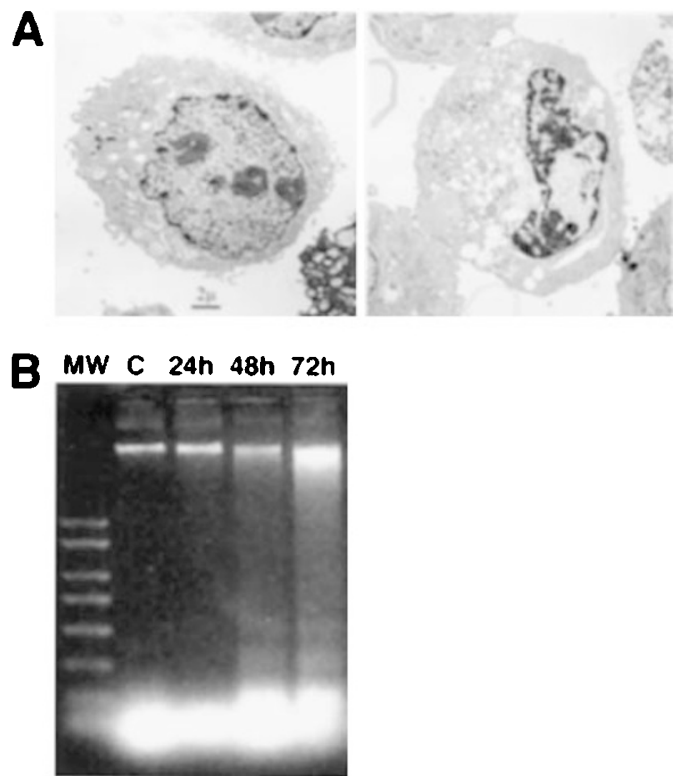

Figure 2 (A) Morphological changes in control (left) and PUVA-treated (right) JB6 cells $24 \mathrm{~h}$ after treatment $(6000 \times)$. Morphological features of apoptosis such as chromatin condensation at the nuclear periphery and cytoplasmic vesiculation are prominent in the PUVA-treated cell. (B) PUVA-induces DNA fragmentation in JB6 epidermal cells. Agarose gel electrophoresis of DNA from ethanol-treated JB6 cells (lane C) and from cells 24,48 , and $72 \mathrm{~h}$ after PUVA treatment. MW, molecular weight markers 
The results of three independent experiments are shown in Figure 3A. Fluorescence activated cell sorting (FACS) analysis revealed an average of 9,22 , and $60 \%$ TUNELpositive cells in the PUVA-treated cells at 24,48 , and $72 \mathrm{~h}$, respectively. There were fewer than $5 \%$ apoptotic cells in the groups treated with ethanol, 8-MOP, or UVA alone. The differences between ethanol and PUVA-treated cells were statistically significant at 48 and $72 \mathrm{~h}$ after PUVA with $P$ values of $<0.01$ (two-tailed $t$-test). To confirm the FACS data, we used fluorescence microscopy to visualize DNA strand breaks. PUVA-treatment resulted in the detection of TUNEL-positive cells; ethanol-treated cells however, did not appear to be TUNEL-positive (data not shown). Thus, the qualitative and quantitative data obtained from these experiments indicated that apoptosis does occur in JB6 mouse epidermal cells treated with PUVA and that DNA fragmentation is a relatively late event.

\section{PUVA treatment induces caspase-3 activity in JB6 cells}

A significant amount of data supports a role for caspase-3 in apoptosis following exposure to a variety of DNA-damaging
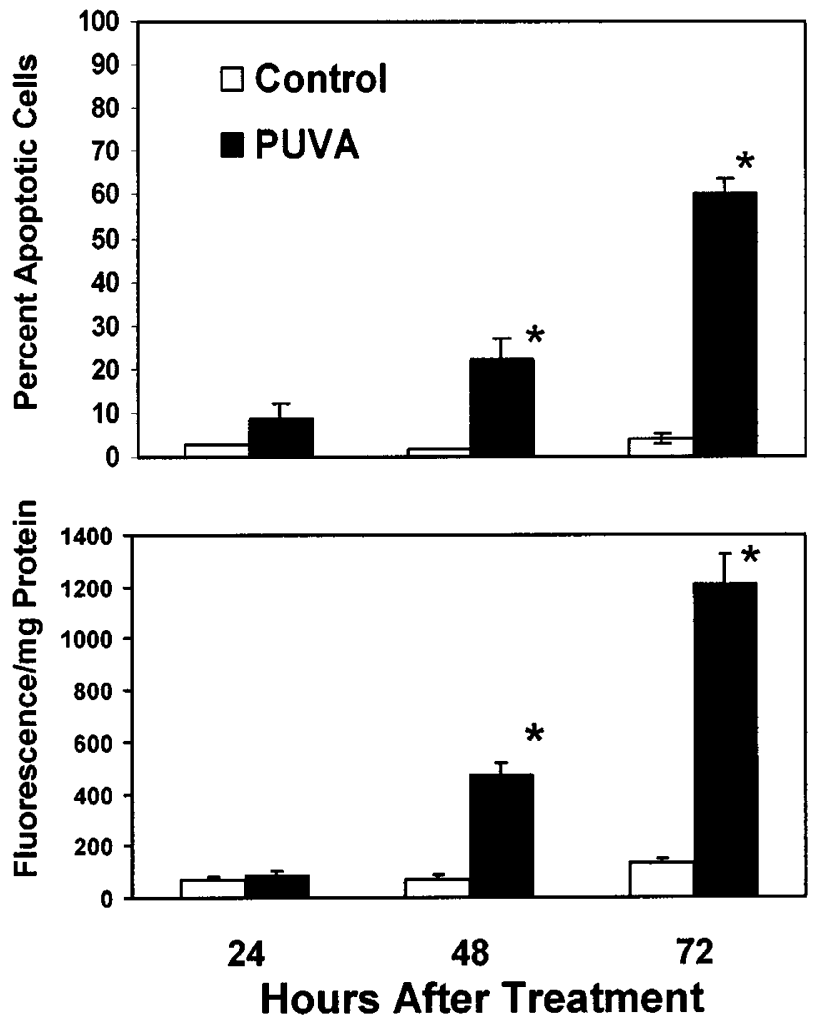

Figure 3 (A) TUNEL analysis of JB6 epidermal cells after PUVA treatment. Control represents cells treated with $1 \%$ ethanol. The differences in percentages of apoptotic cells between control and PUVA-treated groups were statistically significant at 48 and $72 \mathrm{~h},\left({ }^{*}=P\right.$ value $\left.<0.01\right)$. Data represent means + S.E. of triplicate measurements. (B) Caspase-3 activity in PUVA treated JB6 cells. Caspase- 3 activity was statistically significant at 48 and $72 \mathrm{~h}$ after PUVA treatment as compared to control (ethanol treatment) $\left({ }^{*}=P\right.$ value $<0.001)$. Data represent means $\pm S E$ of triplicate measurements agents. $^{42}$ Caspases are involved in the proteolysis of cytoskeletal and other proteins involved in cellular integrity and cell adhesion. Cleavage of such proteins helps the dying cell to detach and round up, making it easier to be disposed of. We measured caspase-3 activity to determine whether caspases are involved in PUVA-induced apoptosis. As shown in Figure $3 \mathrm{~B}$, caspase-3 activity was significantly increased in PUVA-treated cells at 48 and $72 \mathrm{~h}$ after PUVA treatment. This observation is temporally consistent with the appearance of DNA fragmentation detected by the ladder assay and FACS analysis. There was no change in caspase-3 activity in 8-MOP or UVA alone treated cells (data not shown).

\section{Induction/stabilization of p53 in PUVA-treated JB6 cells}

Because PUVA treatment induces DNA damage, which is known to result in activation and/or stabilization of p53, we analyzed PUVA-treated JB6 cells for p53 expression at various times after treatment. A representative Western blot shown in Figure $4 \mathrm{~A}$ reveals that PUVA treatment caused increased expression of p53 by $6 \mathrm{~h}$, which reached peak levels by 24 to $48 \mathrm{~h}$. In contrast, p53 levels were undetectable in JB6 cells treated with ethanol, 8-MOP, or UVA alone (data not shown). Note that the two distinct bands, p50 and p40, that migrated below $53 \mathrm{kD}$ consistently appeared after PUVA treatment and may be cleavage products resulting from in vivo or in vitro protease activation; several investigators have reported the generation of similar p53-cleavage products in cell-free systems. ${ }^{43-45}$ Alternatively, the bands may be the result of nonspecific binding of the p53 antibody to an unknown neoantigen.

To assess whether the p53 protein was phosphorylated, we performed Western blot analyses with lysates of ethanol- and PUVA-treated cells and antibodies specific

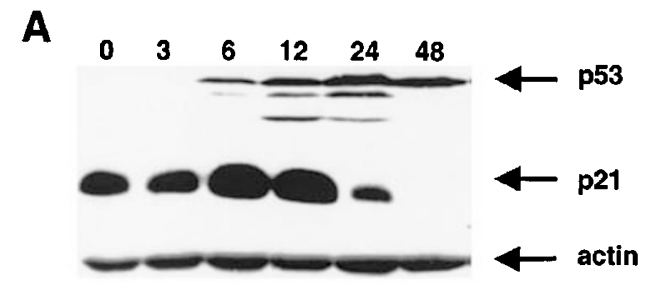

B

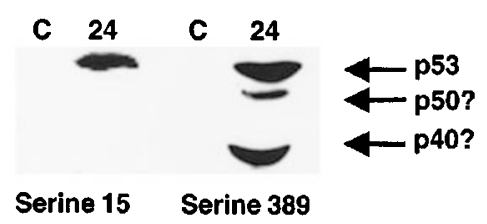

Figure 4 (A) Western blot showing induction of $\mathrm{p} 53$ and $\mathrm{p} 21^{\text {Waf1/Cip } 1}$ in JB6 cells after PUVA treatment. The actin immunoblot shows equal protein loading. (B) Western blot analysis of ethanol treated (lane C) and PUVAtreated cell extracts ( $24 \mathrm{~h}$ post treatment) for expression of p53 phosphorylated at serines 15 and 389 . p50? and p40? probably represent degradative products of $\mathrm{p} 53$ 
for phosphorylated sites on p53. As shown in Figure 4B, p53 was phosphorylated at serine 15 (aminoterminus) and serine 389 (carboxyterminus) in PUVA-treated cells at $24 \mathrm{~h}$. Interestingly, the two bands corresponding to cleavage products ( 550 and p40) of p53 were also phosphorylated at serine 389 but these two bands were absent in the blot probed with p53 serine 15-specific antibody. These results suggest that $\mathrm{p} 50$ and $\mathrm{p} 40$ cleavage products are missing portions of p53 at the $\mathrm{N}$ terminus. Nonetheless, the phosphorylation data provide evidence that p53 may be functionally activated by PUVA treatment. In contrast, exposure to ethanol (Figure 4B), UVA, or 8-MOP (data not shown) did not result in the phosphorylation of p53.

\section{Induction of p21 ${ }^{\text {Waf1/Cip } 1}$ in PUVA-treated JB6 cells}

There is a great deal of evidence indicating that after DNA damage, p53 can transcriptionally activate p21 Waf1/Cip1, a cyclin-dependent kinase inhibitor. ${ }^{29,46}$ Furthermore, p21 Waf1/Cip1 forms a quaternary complex with cyclins and cyclin-dependent kinases that prevents them from phosphorylating targets required for cellular proliferation. In addition, p21 Waf1/Cip1 can also directly affect DNA replication through its interaction with proliferating cell nuclear antigen. ${ }^{46}$ In PUVA-treated JB6 cells, the levels of $\mathrm{p} 21^{\text {Waf } 1 / \text { Cip } 1}$ increased at 6 to $12 \mathrm{~h}$, decreased at $24 \mathrm{~h}$, and were undetectable at $48 \mathrm{~h}$ after treatment (Figure $4 \mathrm{~A}$ ), indicating that $\mathrm{p} 21^{\text {Waf1/Cip1 }}$ may be involved in regulating cell-cycle arrest in PUVA-treated cells. Induction of p21 Waf1/Cip1 appeared to be a relatively early event, occurring between 6 and $12 \mathrm{~h}$ after treatment, perhaps to cause cell-cycle arrest to allow for DNA repair.

We also analyzed PUVA-treated JB6 cells for expression of $\mathrm{Bcl}-2$ and $\mathrm{Bax}$, two candidate p53 targets that play wellestablished roles in apoptosis. ${ }^{47}$ However, we did not detect changes in Bcl-2 or Bax levels at any time point examined (data not shown). This was not surprising, as the role of these proteins in preventing or promoting apoptosis may depend upon their subcellular localization or whether they form dimers and not necessarily upon changes in the levels of their expression. ${ }^{48}$

\section{PUVA treatment causes nuclear translocalization of p53 in JB6 cells}

The Western blot data provided evidence for increased expression or stabilization of p53. As a surrogate marker to determine whether p53 was functionally activated after PUVA treatment, we analyzed p53 localization to the nucleus by immunofluorescence staining and confocal microscopy using a fluorescein isothiocyanate (FITC)conjugated antibody to detect p53 and propidium iodide (PI) to detect the nucleus. Figure 5 shows that the p53 protein was translocated to the nucleus at $6 \mathrm{~h}$ after treatment in PUVA-treated cells but not in ethanol-treated control cells. These data suggest that p53 is activated as early as $6 \mathrm{~h}$ after PUVA treatment, most likely to function as a transcription factor for proteins involved in cell-cycle arrest, DNA repair, and/or apoptosis.

\section{PUVA treatment induces Fas expression in JB6 cells}

Because wild-type p53 is known to transcriptionally activate Fas, which is known to play a key role in apoptosis, we investigated whether PUVA treatment induces Fas expression in JB6 cells. The results shown in Figure 6 indicate that while ethanol- and PUVA-treated cells expressed similar amounts of Fas protein on their surface at $24 \mathrm{~h}$ as measured by increasing Fas-conjugated phycoerythrin (PE) levels, a population of PUVA-treated cells expressing more Fas on their surface appeared at $48 \mathrm{~h}$. In addition, at $72 \mathrm{~h}$, almost all of the PUVA-treated cells expressed significantly more Fas on their surface compared to ethanol treated cells. However, level of Fas expression in 8-MOP or UVA alone treated cells remained the same as ethanol treated cells (data not shown). These results indicate that Fas/FasL interactions may play a role in PUVA-induced apoptosis in JB6 cells.

\section{PUVA treatment fails to induce apoptosis in $p 53^{-1}$ and gld mice}

As discussed before, most DNA-damaging agents induce apoptosis via a p53-mediated pathway, although apoptosis may be induced in a p53-independent manner as well. ${ }^{32-34}$ To determine whether PUVA-induced apoptosis requires functional p53 and Fas/FasL interaction, we treated $p 53^{-1-}$ and gld $\left(\right.$ fasL $\left.^{-1-}\right)$ mice, along with wild-type $\left(p 53^{+/+}\right.$and fasL $^{+++}$) mice with PUVA and analyzed their skin for the presence of TUNEL-positive cells at various times posttreatment. Representative data shown in Figure 7 reveal the presence of numerous TUNEL-positive cells in the epidermis of PUVA-treated wild-type mice at $72 \mathrm{~h}$ post-treatment. In contrast, very few TUNEL-positive cells were present in the epidermis of PUVA treated $p 53^{-1-}$ and gld mice at $72 \mathrm{~h}$ post treatment. Quantitative data shown in Figure 8 reveal that wild-type mice had $22-36 \%$ TUNEL-positive cells compared to $8-15 \%$ in $p 53^{-1-}$ mice and only $2 \%$ in the gld mice at $24-$ $72 \mathrm{~h}$, respectively. These data represent statistically significant differences with $P$ values of $<0.01$ and $<0.001$ (twotailed $t$-test) and provide compelling evidence that both p53 and FasL are required for the apoptotic response in mice exposed to PUVA. As expected, TUNEL-positive cells were absent in 8-MOP or UVA alone treated mice regardless of genotype (data not shown).

\section{PUVA treatment causes increased expression of Fas and FasL in $\mathrm{p53}^{+++}$mouse skin}

Previous studies have shown that Fas/FasL interaction is required for UV-induced apoptosis. ${ }^{49,50}$ To determine whether p53-dependent apoptosis in PUVA-treated mice involves Fas and FasL interactions, PUVA-treated skin from $p 53^{+/+}$and $p 53^{-1-}$ mice were analyzed for Fas and FasL expression by immunohistochemical staining. The results shown in Figure 9 indicate that both wild-type and $p 53^{-1-}$ mice treated with PUVA expressed more Fas (Figure 9A) and FasL (Figure 9B) in the epidermis compared to ethanol-treated control mice. However, there appeared to be more Fas and FasL expression in the epidermis of PUVA treated $p 53^{+/+}$mice 

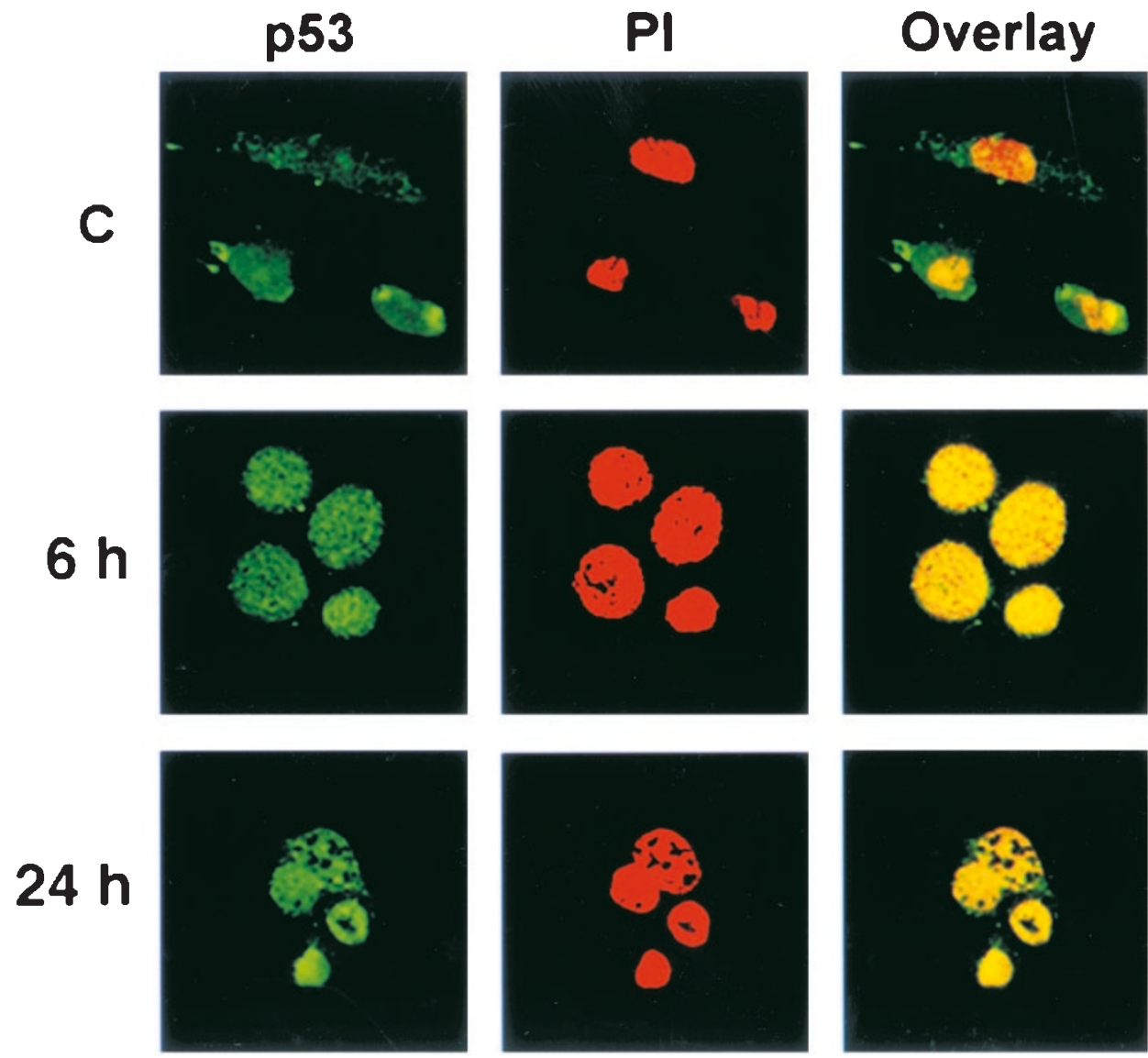

Figure 5 Confocal laser scanning microscopy of PUVA-treated JB6 cells showing translocation of p53 from the cytoplasm to the nucleus. The cells were stained with pan-p53 antibody followed by a FITC-conjugated secondary antibody (green color) (left panels). DNA was stained with PI to identify the nucleus (red color) (middle panels). The overlays show p53 staining superimposed on PI staining (yellow color) (right panels) $(600 \times)$

than in the epidermis of $p 53^{-1-}$ mice at $48 \mathrm{~h}$ post treatment, suggesting that p53 may be required to transcriptionally activate Fas, which in turn affects FasL levels. Immunohistochemical analysis also revealed that the p53 levels increased in $p 53^{+/+}$and $g / d$ mice at 24 to $72 \mathrm{~h}$ after PUVA and the protein was phosphorylated at serine 15 (data not shown), indicating functional activation of p53. Again, 8-MOP or UVA alone did not cause increased expression of Fas and FasL in wild-type, $p 53^{+/+}$or $p 53^{-/-}$mouse skin (data not shown).

\section{Discussion}

In this study, we have demonstrated that treatment of mouse epidermal cells with PUVA results in cell death by apoptosis in vitro and in vivo. That cell death resulted from the synergistic action of PUVA is clear because, at the doses used, neither 8MOP nor UVA alone were cytotoxic to JB6 cells or to epidermal cells in wild-type, $p 53^{-1-}$, and gld mice. We used several criteria to demonstrate that PUVA-induced cell death in mouse epidermal cells involves apoptosis. First, TEM studies revealed that PUVA-treated cells exhibit many of the characteristic morphological features of apoptosis, including nuclear condensation, cytoplasmic vesiculation, and the formation of apoptotic bodies. Second, PUVA treatment of
JB6 cells produced a faint pattern of DNA ladders at 48 and $72 \mathrm{~h}$. Third, TUNEL analysis provided quantitative data demonstrating that PUVA-treated cells underwent DNA fragmentation. More importantly, PUVA treatment also caused cell death by apoptosis in vivo, as detected by the TUNEL assay. The time course for the apoptotic response in vivo was similar to that in vitro, as the cells underwent apoptosis $48-72 \mathrm{~h}$ after PUVA treatment in both cases. Apoptosis, from the initial cell shrinkage to the removal of apoptotic bodies, requires up to $72 \mathrm{~h}$ in epidermal cells, ${ }^{51}$ which is consistent with what we observed. Our finding that PUVA induces apoptosis in mouse epidermal cells is in agreement with other reports. One study reported that PUVA induces apoptosis in the squamous cell carcinoma cell line A431 as shown by annexin $\mathrm{V}$ binding and PI uptake. ${ }^{52}$ In addition, a case report of the use of PUVA therapy to achieve remission in a patient with adult $\mathrm{T}$ cell leukemia indicated that the leukemic cells died by apoptosis based on TEM findings. ${ }^{53}$ Another report showed that PUVA treatment induced sunburn cells and DNA fragmentation in rat skin. ${ }^{21}$ However, none of these studies investigated the underlying mechanisms in PUVA-induced apoptosis.

Several studies have shown that agents that damage DNA induce high levels of $p 53^{24,25,27}$ and accumulation of $p 53$ in 


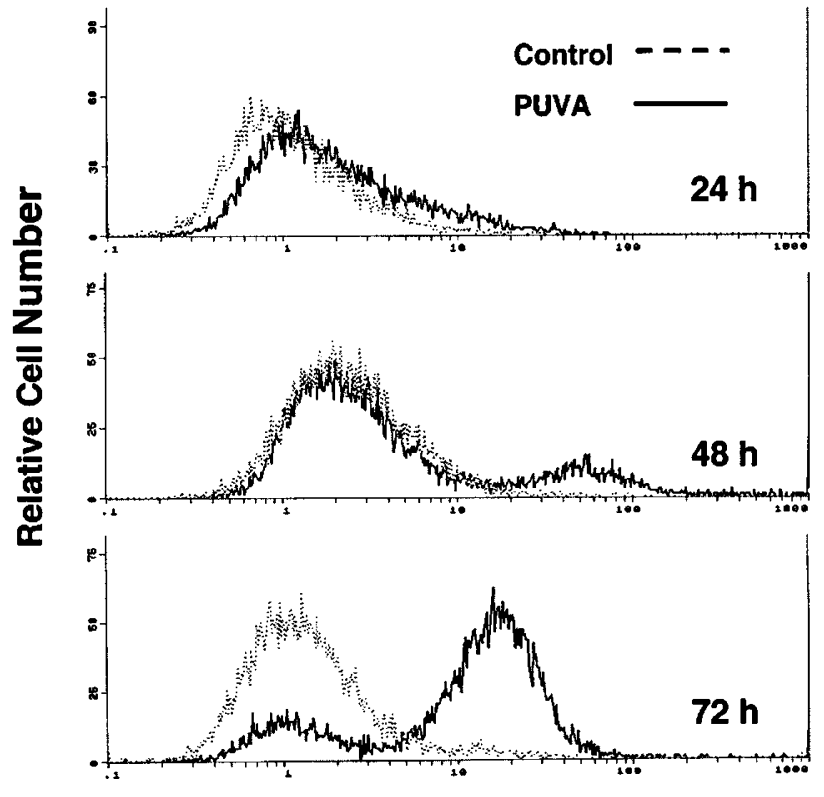

\section{PE Fluorescence}

Figure 6 Surface levels of Fas expression on JB6 cells at 24 to $72 \mathrm{~h}$ after PUVA treatment. Control and PUVA-treated cells were stained with a PEconjugated anti-Fas antibody and analyzed by FACS to quantify the expression of Fas

the nucleus. ${ }^{54,55}$ Our data also demonstrate that PUVA treatment of JB6 mouse epidermal cells results in both stabilization of p53 and its translocation to the nucleus as early as $6 \mathrm{~h}$ after PUVA treatment. In addition, we found that p53 was phosphorylated at serine 15 on the $\mathrm{N}$ terminus and at serine 389 on the $\mathrm{C}$ terminus, providing further evidence for p53 activation. Although some studies have shown that PUVA treatment induces p53 in the reconstituted human-skin equivalent EpiDerm ${ }^{37}$ and in the skin of psoriasis patients ${ }^{38}$ these studies did not address the question of whether PUVA induces apoptosis. Here, we demonstrate that PUVA induces apoptosis in mouse epidermal cells in vitro and in vivo and involves the p53 pathway.

In addition to UVB $(280-320 \mathrm{~nm})$, UVA radiation is known to induce p53 in MCF-7 cells, human epidermal cells, and keratinocytes. ${ }^{56-59}$ However, we did not detect p53 induction in JB6 cells treated with UVA alone. Perhaps this discrepancy could be due to the fact that the dose $(20 \mathrm{~kJ} /$ $\mathrm{m}^{2}$ ) of UVA used in our studies was very low compared to those in other studies $\left(150-200 \mathrm{~kJ} / \mathrm{m}^{2}\right) .{ }^{56-59}$ Moreover, because irradiation of JB6 cells with $20 \mathrm{~kJ} / \mathrm{m}^{2}$ UVA alone did not cause cell death, the UVA dose we used may not be high enough to inflict DNA damage and induce p53.

In addition to induction and translocation of the p53 protein from the cytoplasm to the nucleus, PUVA treatment also induced $\mathrm{p} 21^{\text {Waf1/Cip1 }}$ expression. PUVA induction of p21 Waf1/Cip1 closely followed p53 induction and translocation, which suggests that $\mathrm{p} 21^{\text {Waf1/Cip1 }}$ was transcriptionally activated by $\mathrm{p} 53$. However, p21 Waf1/Cip1 expression began to decrease $24 \mathrm{~h}$ after PUVA treatment and was undetectable $48 \mathrm{~h}$ after treatment, perhaps because p21 Waf1/Cip1 was rapidly degraded. DNA-damaging agents, including UV, ionizing radiation, and a variety of chemical and biological agents, have been reported to activate p21 ${ }^{\text {Waf1/Cip } 1}$ in a p53-dependent manner. ${ }^{29,60}$ Many of the proteins associated with apoptosis are also involved in the control of proliferation, providing further evidence for the important link between cell-cycle progression and apoptosis. Therefore, we can hypothesize that in PUVA-treated cells, p21 Waf1/Cip1 causes cell-cycle arrest and then the cells begin to undergo apoptosis, perhaps as a result of their inability to repair damaged DNA. During this time, caspases may cleave key regulatory and structural proteins that are necessary for maintaining the integrity of the plasma membrane, cytoskeleton, and nucleus. ${ }^{42}$ This hypothesis is supported by our finding that PUVA treatment caused a significant increase in caspase-3 activity in PUVA-treated JB6 cells at 48 to $72 \mathrm{~h}$ after treatment.

Given that other DNA-damaging agents induce high levels of $p 53^{24-27,61}$ and $p 53$ has been reported to be involved in the induction of apoptosis, ${ }^{22,23,62}$ it is reasonable to hypothesize that $\mathrm{p53}$ is also required for PUVAinduced apoptosis. One study reported the involvement of p53 in the induction of apoptosis in tumor-promotorsensitive $(P+)$ and promotion-insensitive $(P-)$ JB6 cells following treatment with phenethyl isothiocyanate (PEITC), a chemoprotective agent. ${ }^{63}$ The authors reported that PEITC inhibited tumor promoter-induced cell transformation and induced apoptosis in the JB6 C141 cell line. The same concentrations of PEITC caused p53 transactivation in a dose- and time-dependent manner, which led the investigators to conclude that p53 was associated with the apoptotic response. This observation was supported by the fact that PEITC induced apoptosis in $p 53^{+/+}$but not in $p 53^{-1-}$ cells. More importantly, our in vivo data in $p 53^{-1-}$ mice provide compelling evidence that p53 is required for the apoptotic response in PUVA-treated mouse epidermal cells. There was a statistically significant difference between the numbers of apoptotic cells in the $p 53^{+/+}$and $p 53^{-1-}$ mice at 24,48 , and $72 \mathrm{~h}$. However, there were 8$15 \%$ apoptotic cells in the $p 53^{-1-}$ mice after treatment, indicating that other mechanisms may be involved in the response to PUVA treatment. Similarly, it is reported that UVB radiation also induces some apoptosis in the epidermis of $p 53^{-1-}$ mice, but only about one-fourth that observed in $p 53^{+/+}$mice. ${ }^{35,64}$ This may be because other apoptotic pathways such as Fas/FasL get activated, even in the absence of p53 after PUVA treatment.

Recent in vivo studies have shown that Fas/FasL interaction is required for the elimination of UV-damaged sunburn cells and that loss of FasL contributes to the development of UV-induced skin cancer. ${ }^{49,50}$ Binding of FasL to Fas activates an apoptotic cascade in a variety of cell types exposed to diverse stimuli. The interaction of Fas/FasL plays a critical role in the depletion of peripheral $T$ lymphocytes ${ }^{65}$ and the maintenance of immunological privilege by eliminating inflammatory cells. ${ }^{66}$ Following activation by FasL, the intercellular death domain of Fas oligomerizes and recruits the adaptor protein called Fasassociated death domain (FADD). ${ }^{67-69}$ The death effector domain of FADD recruits the initiator procaspase- 8 to the 

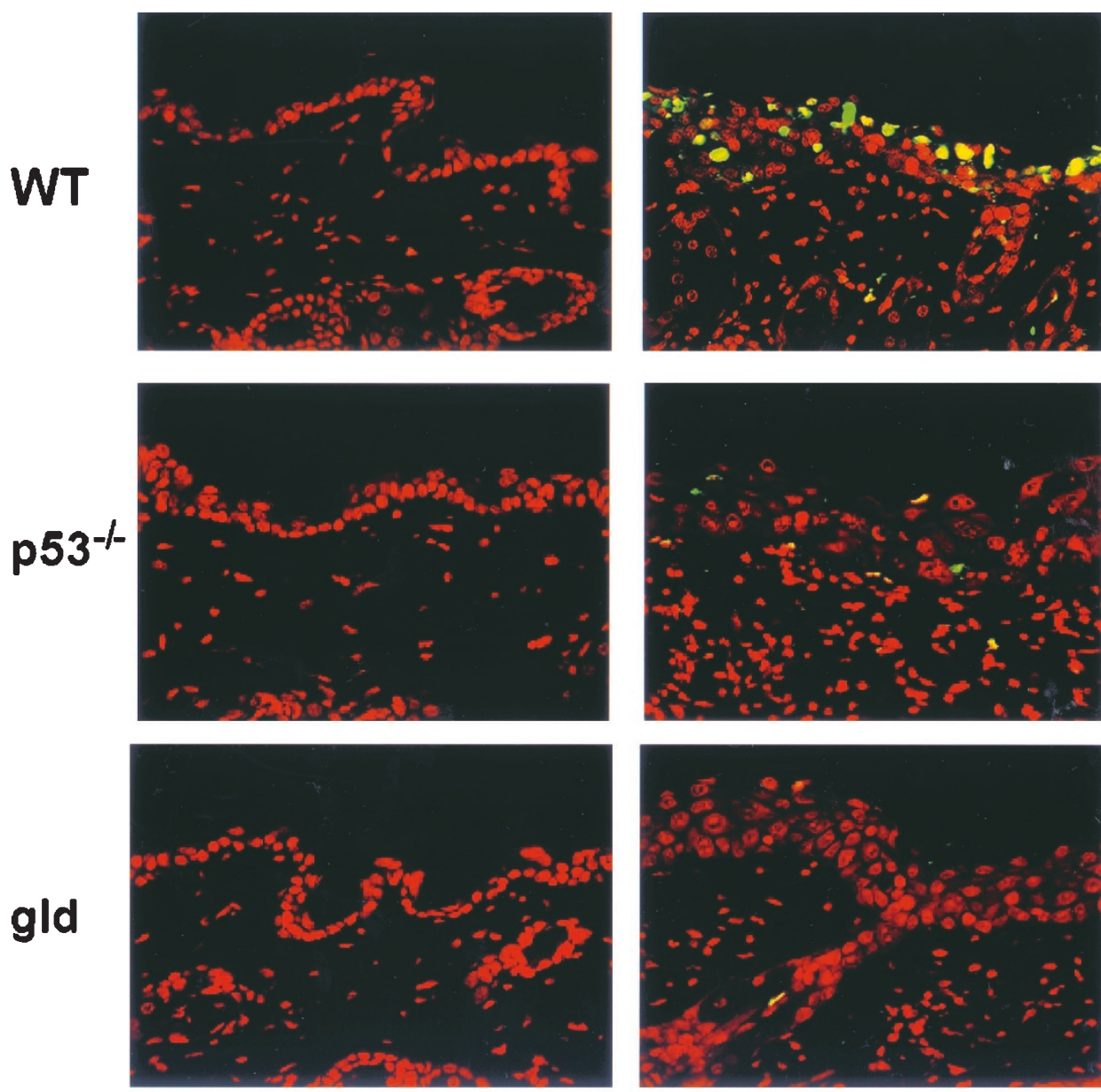

\section{Control}

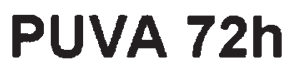

Figure 7 Fluorescence microscopic images of TUNEL-positive cells (green and yellow colors) from ethanol- and PUVA-treated wild-type, $p 53^{-1-}$, and gld mice $72 \mathrm{~h}$ after treatment. The nuclei were stained with PI as indicated by the red color. TUNEL-positive cells were stained with FITC and appear yellow-green. Original magnification, $200 \times$

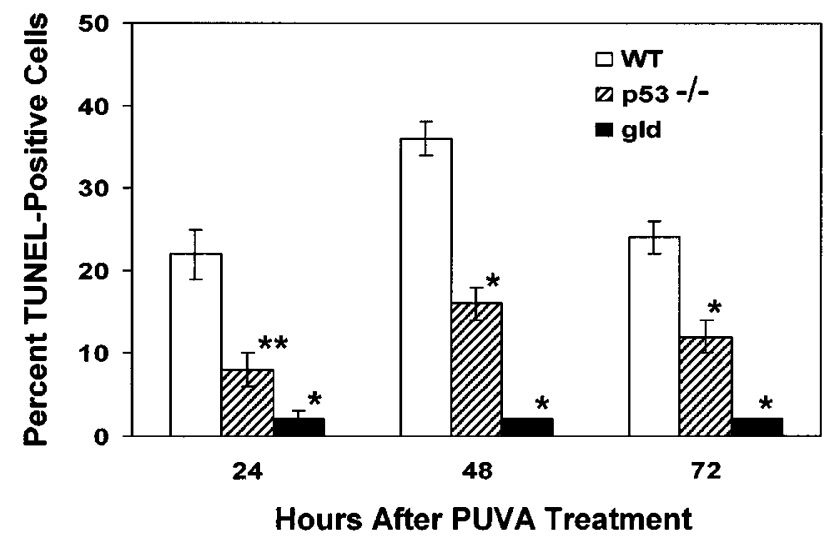

Figure 8 Quantification of TUNEL-positive cells in PUVA-treated skin from wild-type, $p 53^{-1-}$, and gld mice. The data are the mean counts from four $200 \times$ fields from two mice per group \pm S.E. ${ }^{* *}=P$ value $<0.01,{ }^{*}=P$ value $<0.001$ death inducing signaling complex. Autocatalytic cleavage and activation of downstream executioner caspases eventually leads to apoptosis. Surface Fas levels can be transcriptionally increased by $p 53{ }^{70}$ or through a transcription-independent mechanism involving its translocation from the golgi to the cell's surface. ${ }^{71}$ The levels of surface Fas expression increased significantly in PUVA-treated JB6 cells $48-72 \mathrm{~h}$ after treatment. Because Fas is a transcriptional target of p53, it is likely that after PUVA treatment, p53 induces Fas expression, which in turn activates caspase-3, ultimately resulting in apoptosis. This conclusion is supported by the finding that PUVA treatment induced Fas expression as well as caspase-3 activity in JB6 cells $48-72 \mathrm{~h}$ after PUVA.

The apparently higher levels of Fas and FasL expression in $p 53^{+/+}$mice than in $p 53^{-1-}$ mice after PUVA treatment further suggests that p53 may mediate apoptosis by transcriptionally regulating Fas expression. Our finding that TUNEL-positive cells were totally absent in PUVA treated gld mice indicates that Fas/FasL interactions are absolutely 


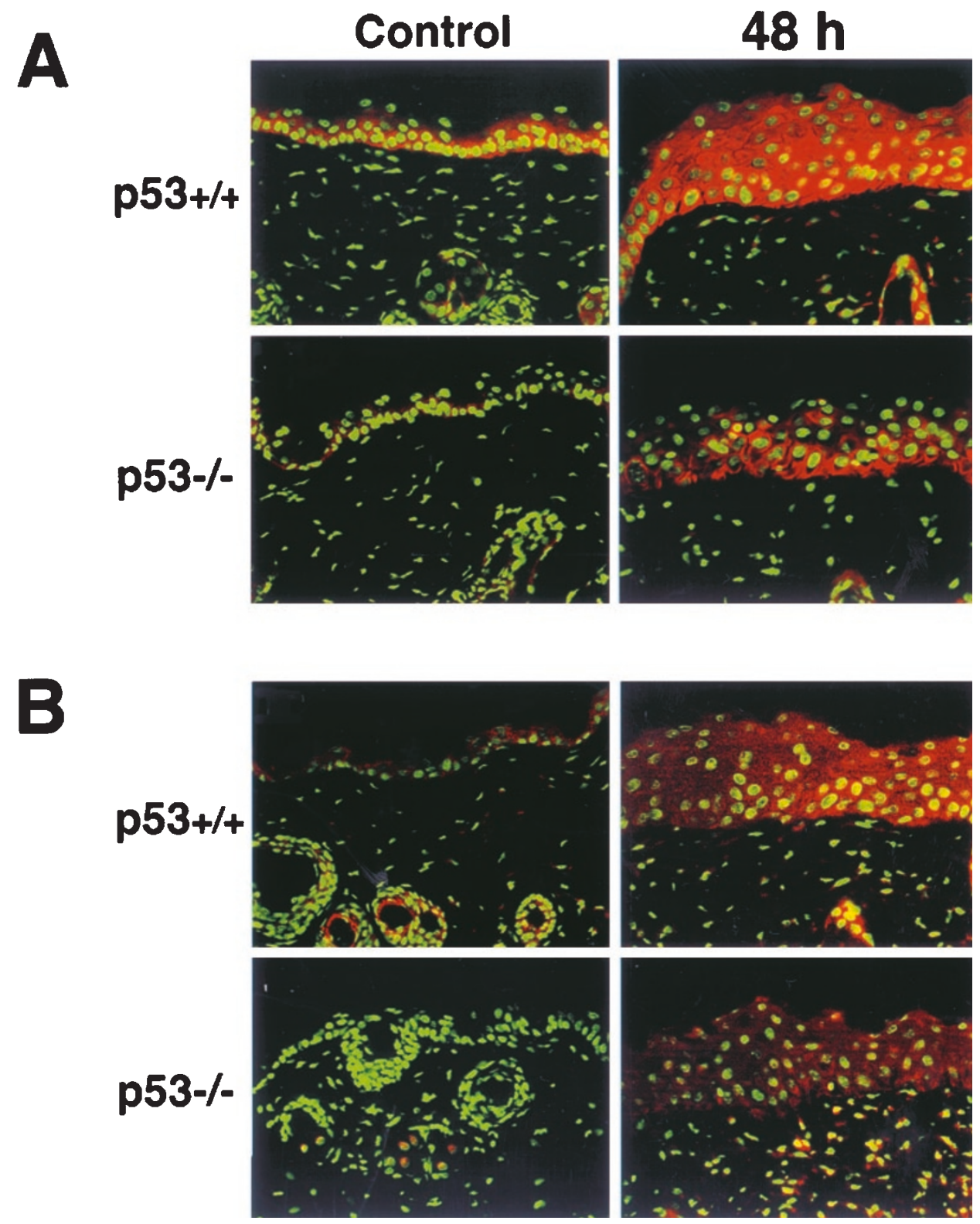

Figure 9 Immunohistochemical analysis of Fas (A) and FasL (B) in $p 53^{+/+}$and $p 53^{-1-}$ mice $48 \mathrm{~h}$ after PUVA treatment. A secondary Cyanine-5-conjugated antibody, which appears red, was used to identify the proteins. The nuclei were counterstained with the green dye Sytox. Original magnification, $200 \times$

required for PUVA-induced apoptosis. Fas is constitutively expressed on a variety of lymphoid and nonlymphoid cells, including the skin. ${ }^{72,73}$ In addition, studies with gld mice have demonstrated an essential role for FasL in UVBinduced apoptosis. ${ }^{50}$ The similarity between UVB induced apoptosis and PUVA-induced apoptosis seen in $p 53^{-1-}$ and gld mice is quite interesting because UVB and PUVA do not cause the same type of DNA damage. While UVB induces primarily cyclobutyl pyrimidine dimers and pyrimidine(6-4)pyrimidone photoproducts, ${ }^{74}$ PUVA induces monofunctional adducts and DNA cross-links. ${ }^{4-7}$ These observations suggest that even though UVB and PUVA induce different types of DNA damage, the pathways leading to apoptosis may be similar or even the same. In summary, our data indicate that PUVA induces apoptosis in mouse epidermal cells in vitro and in vivo, and that p53 and Fas/FasL interactions are essential for this process, at least in vivo. These findings imply that similar mechanisms may be involved in the elimination of hyperproliferative psoriatic keratinocytes from the human skin following PUVA therapy.

\section{Materials and Methods}

\section{PUVA treatment of JB6 cells}

JB6, an immortalized, nontumorigenic epidermal cell line, established from BALB/c mouse skin, ${ }^{75}$ was acquired from the American Type 
Culture Collection (Manassas, VA, USA). The cells were routinely plated in 10-cm dishes with Dulbecco's modified Eagle's Medium (Gibco BRL, Grand Island, NY, USA) containing $10 \%$ bovine calf serum (Gibco $\mathrm{BRL}$ ) at $37^{\circ} \mathrm{C}$ in a $10 \% \mathrm{CO}_{2}$ atmosphere. Eighteen hours later, the medium was removed, and the cells were washed once with phosphate-buffered saline (PBS). 8-MOP (Sigma Chemical Co., St. Louis, MO, USA), diluted in $100 \%$ ethanol, was added to PBS for a final concentration of $10 \mu \mathrm{g} / \mathrm{ml}$. 8-MOP was added to the cells, and they were incubated for $10 \mathrm{~min}$ at $37^{\circ} \mathrm{C}$ in a humidified $5 \% \mathrm{CO}_{2}$ incubator. They were then irradiated with $20 \mathrm{~kJ} / \mathrm{m}^{2}$ UVA from two Mylar-filtered Sylvania F15T8/BLB lamps $(320-400 \mathrm{~nm}$, peak $365 \mathrm{~nm}$; Danvers, MA, USA) without their lids; the Mylar removed all wavelengths shorter than $320 \mathrm{~nm}$. The irradiance of the Mylar-filtered F15T8/BLB lamps was $32 \mathrm{~W} / \mathrm{m}^{2}$, as measured by a spectroradiometer (IL 700A; International Light, Inc., Newburyport, MA, USA). After irradiation, the cells were washed once with PBS and incubated at $37^{\circ} \mathrm{C}$. Control cells were mock-treated with PBS containing $1 \%$ ethanol, 8-MOP, or UVA irradiation alone. The entire operation was performed with the overhead room lights and tissue-culture hood fluorescent lights off.

\section{Mice}

Seven-week old C57BL/6 wild-type, $p 53^{-1-}$, and gld mice were purchased from the Jackson Laboratories (Bar Harbor, MA, USA). We did not use $\operatorname{lpr}\left(\mathrm{Fas}^{-1-}\right.$ ) mice because it is a leaky mutation and the mice can express some Fas. Such expression may affect how epidermal cells respond to PUVA in vivo and could cause confounding results. The animals were permitted to adapt to our animal facility for 1 week in a room with alternating 12-h light and dark cycles and controlled temperature and humidity. Water and food were provided ad libitum. All animal procedures and facilities were reviewed and approved by the University of Texas M.D. Anderson Cancer Center Institutional Animal Care and Use Committee.

\section{PUVA treatment of mice}

Wild-type C57BL/6, p53 ${ }^{-1-}$, and gld mice were divided into four groups of six animals each. Their backs were shaved with electric clippers. Each group of mice received either topical application of vehicle (100\% ethanol), 8-MOP (100 $\mu \mathrm{g}$ per $\left.4 \mathrm{~cm}^{2}\right)$, UVA $\left(50 \mathrm{~kJ} / \mathrm{m}^{2}\right)$, or both 8-MOP and UVA (PUVA). The animals were placed in standard cages covered with Mylar under six UVA lamps that emitted $4.5 \mathrm{~W} / \mathrm{m}^{2}$, as measured by a spectroradiometer. Each cage held five mice placed in individual compartments separated with Plexiglas dividers. The animals were placed aside for $30 \mathrm{~min}$ to allow the 8-MOP to penetrate the skin. The cages containing the UVA and PUVA-treated mice were then placed on a shelf below the UVA lamps for the duration of the exposure. At 24, 48, and $72 \mathrm{~h}$ after PUVA treatment, two mice from each group were randomly selected and killed, and their skins processed for analysis. Dorsal skin (approximately $1 \times 1 \mathrm{~cm}$ ) was excised from the treated area and immediately fixed in $4 \%$ buffered formaldehyde for paraffin-embedded sectioning. The paraffin-embedded skin was cut into $5 \mu \mathrm{m}$ sections for hematoxylin and eosin staining, TUNEL, and immunofluorescence analysis.

\section{JB6 cell viability}

A method developed by Mosmann was used to select an appropriate dose of 8 -MOP and UVA for use in PUVA treatment. ${ }^{76}$ Cells were plated at a density of $10^{4}$ cells/well in 96-well microtiter plates for $24 \mathrm{~h}$ and treated with $1 \%$ ethanol vehicle or various concentrations of 8MOP and/or UVA. At specified times after treatment, $20 \mu \mathrm{l}$ of 3-(4-5- dimethylthiazol-2-yl)-2,5-diphenyltetrazolium bromide (MTT, $1 \mathrm{mg} / \mathrm{ml}$ in PBS; Sigma Chemical Co.) was added to the wells containing $200 \mu \mathrm{l}$ of medium. After a $4-\mathrm{h}$ incubation at $37^{\circ} \mathrm{C}$, the medium/MTT mixture was replaced with $100 \mu \mathrm{l}$ of DMSO (Sigma Chemical Co.). $\mathrm{OD}_{570}$ was measured after 30 min with a 96-well microtiter plate spectrophotometer (Cerus UV900C; Lionheart Technologies, Inc., Carson City, NV, USA). Cell survival was calculated as a percentage of the OD of control (ethanol treated) cells in order to select an appropriate dose of PUVA.

The trypan blue dye exclusion assay was used to determine the number of viable cells just prior to PUVA treatment and at 24,48 , and $72 \mathrm{~h}$ after PUVA treatment. Cells were plated at a density of $2 \times 10^{6}$ cells/plate in $10 \mathrm{~cm}$ plates for $24 \mathrm{~h}$ and then treated with $1 \%$ ethanol vehicle, 8-MOP, UVA, or PUVA, as described. Dishes from each treatment group were randomly selected, trypsinized and an aliquot of cells was counted in a suspension of $0.1 \%$ trypan blue dye. Only viable cells were counted to determine percent cell survival after treatment, which was calculated as a percentage of the cells that were counted at time 0 for each respective group.

\section{DNA ladder formation}

The ladder assay is based on the oligonucleosomal DNA fragmentation of nuclear DNA that can be visualized by ethidium bromide staining following electrophoresis as previously described. ${ }^{77}$ JB6 cells were plated in $10-\mathrm{cm}$ dishes $\left(2 \times 10^{6}\right.$ cells/dish) and treated with PUVA, 8-MOP, UVA, or $1 \%$ ethanol vehicle. At 24,48 , and $72 \mathrm{~h}$, cells were trypsinized and combined with floating cells in the same culture. DNA was isolated by lysing the cells in $500 \mu \mathrm{l}$ of $0.2 \%$ Triton-X, $20 \mathrm{mM}$ EDTA, and $1 \mathrm{mM}$ Tris, $\mathrm{pH} 8.0$, for $20 \mathrm{~min}$ on ice. The DNA fragments were harvested by centrifugation for $15 \mathrm{~min}$ at $14000 \times \mathrm{g}$. After the addition of $600 \mu \mathrm{l}$ of isopropanol and $100 \mu \mathrm{l}$ of $5 \mathrm{M} \mathrm{NaCl}$, the DNA in the supernatant was precipitated for $24 \mathrm{~h}$ at $-20^{\circ} \mathrm{C}$, centrifuged at $14000 \times g$ for $10 \mathrm{~min}$, dried, and incubated for $1 \mathrm{~h}$ at $65^{\circ} \mathrm{C}$ in TE buffer containing $0.2 \mathrm{mg} / \mathrm{ml}$ proteinase $\mathrm{K}$ and $1 \mathrm{mg} / \mathrm{ml}$ RNAse A. The DNA fragments were resolved by electrophoresis at $100 \mathrm{~V}$ on $1.5 \%$ agarose gels impregnated with ethidium bromide, detected by UV transillumination, and photographed.

\section{Terminal deoxyribonucleotidyl transferase mediated dUTP nick-end labeling (TUNEL) assay in JB6 cells}

After PUVA treatment, adherent cells were trypsinized and combined with nonadherent cells of the same culture. DNA nick end labeling was performed with the fluorescein apoptosis detection system kit (Promega Biotech, Madison, WI, USA). Control and treated cells were fixed, permeabilized, and incubated with terminal deoxyribonucleotidyl transferase that catalyzes the addition of FITC-labeled deoxyuridine triphosphates to the $3^{\prime}$ ends of double- and singlestranded DNA. The cells were counterstained with propidium iodide (PI) to identify the nuclei of the cells for sorting. The flow cytometer detected fluorescence at $623 \mathrm{~nm}$ for PI and at $520 \mathrm{~nm}$ for fluorescein. The cells were analyzed by FACS and the percentages of apoptotic cells were determined with EPICS Elite Software. Ten thousand cells were evaluated for each sample, and the data are taken from one experiment representative of the three performed.

\section{TUNEL assay in mouse skin}

The paraffin embedded 5- $\mu \mathrm{m}$ tissue sections were deparaffinized, hydrated, dehydrated, and analyzed for apoptotic cells using the fluorescein apoptosis detection system kit from Promega Biotech. The 
sections were stained with $\mathrm{PI}$, and apoptotic cells were detected with a Zeiss fluorescent microscope (Carl Zeiss, Inc., Thornwood, NY, USA) using a Hamamatsu C5810 chilled camera (Hamamatsu, Bridgewater, NJ, USA). A composite figure was prepared using Adobe Photoshop software (Adobe Systems, Inc., San Jose, CA, USA). TUNEL-negative and TUNEL-positive cells in a $200 \times$ field were counted with Optimas software (Media Cybernetics, Silver Spring, MD, USA). TUNEL sections were prepared from two mice in every treatment group at all time points, and four fields in each tissue section were examined. The number of TUNEL-positive cells was divided by the total number of cells to determine the percentage of apoptotic cells. The mean values and standard errors were calculated with Excel ${ }^{\mathrm{TM}}$ software (Microsoft, Redmond, WA, USA). A two-tailed $t$-test was performed and $P$ values were calculated to determine significance. $P$ values less than 0.05 were taken as significant.

\section{Caspase-3 assay}

The activity of caspase-3 was measured in ethanol-, 8-MOP, UVA- and PUVA-treated cells using a method developed by Gurtu et al. ${ }^{78}$ Cells were harvested by trypsinization and centrifuged at $3000 \times g$ for $10 \mathrm{~min}$ at 24 to $72 \mathrm{~h}$. The cell pellets were resuspended in lysis buffer (100 mM HEPES, 10\% sucrose, $1 \mathrm{mM}$ EDTA, and a protease inhibitor cocktail (Mini-Tablet $^{\mathrm{TM}}$; Boehringer Mannheim, Indianapolis, IN, USA) on ice. After $20 \mathrm{~min}$, the samples were centrifuged at $14000 \times g$ for $10 \mathrm{~min}$. The supernatant was assayed for caspase-3 activity using $50 \mathrm{nM}$ Ac-DEVD-AFC (Enzyme Systems Products, Livermore, CA, USA), a synthetic fluorogenic substrate consisting of an acetyl group attached to a peptide containing aspartic acid, glutamic acid, valine, and aspartic acid (DEVD). (Caspases can proteolytically cleave between the $D$ and AFC, thereby releasing the fluorogenic molecule, which can be detected by spectrofluorometry). The samples were placed in a $37^{\circ} \mathrm{C}$ water bath for $15 \mathrm{~min}$ and transferred to cuvettes containing $1 \mathrm{ml}$ of lysis buffer. Fluorescence resulting from the release of AFC from DEVD was measured with a RF-1501 spectrofluorometer (Shimadzu Corp., Tokyo, Japan) using an excitation wavelength of $400 \mathrm{~nm}$ and an emission wavelength of $505 \mathrm{~nm}$. Data represent means $\pm S E$ of triplicate determinations. A two-tailed $t$-test was performed, and $P$ values were calculated to determine significance. $P$ values less than 0.05 were deemed significant.

\section{Western blot analysis}

Sodium dodecyl sulfate-polyacrylamide gel electrophoresis (SDSPAGE) was performed to measure protein expression in JB6 cells after PUVA using a method described by Laemmli. ${ }^{79}$ Three to $72 \mathrm{~h}$ after the cells were treated with $1 \%$ ethanol, 8-MOP, UVA, or PUVA, the medium was removed and the monolayer rinsed with cold PBS. The cells were scraped off the plates, added to the medium, and centrifuged at $3000 \times g$ for $5 \mathrm{~min}$. The pellet was rinsed in $1 \mathrm{ml}$ of PBS, centrifuged at $3000 \times g$, and resuspended in

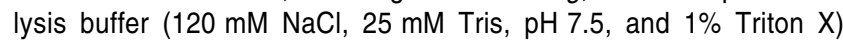
containing a protease inhibitor cocktail (Mini-Tablet ${ }^{\mathrm{TM}}$; Roche Diagnostics, Indianapolis, IN, USA). After the cells were lysed for $20 \mathrm{~min}$ on ice, the lysates were centrifuged at $14000 \times \mathrm{g}$ for $10 \mathrm{~min}$. The protein concentrations were determined by the Bradford assay, ${ }^{80}$ and 20 to $100 \mu \mathrm{g}$ of protein was electrophoresed in $8-12 \%$ SDS polyacrylamide gels at approximately $100 \mathrm{~V}$ for $2 \mathrm{~h}$, depending on the protein of interest. The separated proteins were transferred to $2-\mu \mathrm{m}$ nitrocellulose membranes (Protran; Intermountain Scientific Corp., Kaysville, UT, USA) and blocked with $3 \%$ milk in $250 \mathrm{mM}$ Tris-buffered saline, $\mathrm{pH} 7.4$, with $0.5 \%$ Tween. The blots were probed with antibodies against p53 (Ab-
240; Transduction Laboratories, Lexington, KY, USA), phosphorylated p53 (Ab-ser15 and Ab-ser392; New England Biolabs, Beverly, MA, USA), p21 Waf1/Cip1 (Ab-4; Oncogene Research Products, Cambridge, MA, USA), Bcl-2 (PharMingen, San Diego, CA, USA), and Bax (Santa Cruz Biotechnology, Santa Cruz, CA, USA). To ensure the loading of equal amounts of protein, the blots were probed with anti-actin antibody (Amersham Corp., Arlington Heights, IL, USA). After incubation with the appropriate secondary antibody, signals were detected with chemiluminescent reagents (Pierce, Rockford, IL, USA) and autoradiography.

\section{Immunocytochemical analysis and confocal microscopy}

Treated and control cells grown on poly-L-lysine-coated slides (Sigma Chemical Co) were fixed in $4 \%$ paraformaldehyde, permeabilized with $0.3 \%$ Triton $X-100$, and blocked in $5 \%$ normal horse serum and $1 \%$ normal goat serum. After $1 \mathrm{~h}$, the cells were incubated with 1:100 anti-p53 antibody (pan-p53; Boehringer Mannheim) overnight at $4^{\circ} \mathrm{C}$, washed three times with PBS, and incubated overnight with a FITC-conjugated sheep immunoglobulin $G$ antibody (Boehringer Mannheim) in blocking buffer. The cells were washed in PBS and stained with propidium iodide. The slides were examined with a Zeiss confocal laser scanning microscope with an argon laser (488 nm, $10 \mathrm{mw}$ ), and signals were obtained with a 590-nm PI long-pass filter and a 520-560 nm (FITC) bandpass filter. Digitized images were transmitted to a Macintosh-based image analysis system by using BDS-LSM software (Biological Detection Systems, Pittsburgh, PA, USA). A composite image was prepared with Adobe Photoshop software.

\section{Surface Fas expression on JB6 cells}

Cells were plated at $2 \times 10^{6}$ cells $/ 10 \mathrm{~cm}$ dish and treated with $1 \%$ ethanol, 8-MOP, UVA, or PUVA for 24, 48, and $72 \mathrm{~h}$. Cells were trypsinized, and the pellet was resuspended in FACS buffer (PBS, $2 \%$ FCS, $1 \%$ sodium azide) for $30 \mathrm{~min}$. PE-conjugated anti-mouse Fas antibody (Pharmingen) was added $(1: 20)$ for $30 \mathrm{~min}$. Cells were centrifuged, washed $2 \times$, and resuspended in FACS buffer. The cells were analyzed by FACS, and the amount of fluorescence was determined with EPICS Elite software. Ten thousand cells were evaluated for each sample, and the data are representative of three experiments.

\section{Immunohistochemical analysis of mouse tissue sections}

Briefly, $5-\mu \mathrm{m}$ tissue sections were deparaffinized and treated with target retrieval solution (DAKO, Carpinteria, CA, USA). The sections were washed three times with PBS and blocked with $5 \%$ normal horse serum and 1\% normal goat serum in PBS for $20 \mathrm{~min}$. The slides were incubated overnight at $4{ }^{\circ} \mathrm{C}$ with antibodies specific for p53 (CM5; NovaCastra), Fas (M-20), FasL (N-20), or p21 Waf1/Cip1 (Santa Cruz Biotechnology) diluted 1:100 in serum. After three washes with PBS, the sections were incubated at room temperature for $2 \mathrm{~h}$ with anti-rabbit immunoglobulin $\mathrm{G}$ cyanineconjugated antibody (Jackson Immunoresearch Laboratories, Bar Harbor, MA, USA) diluted 1:200 in serum. The slides were washed three times, and the nuclei were stained with $10 \mu \mathrm{g} / \mathrm{ml}$ Sytox (Molecular Probes, Eugene, OR, USA) in PBS for $2 \mathrm{~min}$ and washed three times with PBS. Excess PBS was removed, Prolong anti-fade reagent (Molecular Probes) was added, and a coverslip 
was placed on each slide. The cells were examined with a Zeiss fluorescence microscope. A composite image was prepared with Adobe Photoshop ${ }^{\mathrm{TM}}$ software.

\section{Acknowledgements}

We thank S Bolshakov, K Ramirez, J Douglas, C Bucana, and K Dunner, Jr. for their excellent technical help, and M Goode and W Pagel for their excellent editorial assistance. This work was supported by National Cancer Institute grants CA 67174 (to HN Ananthaswamy) and CA 16672 (Institutional Core Grant). AB Santamaria and DW Davis were supported by predoctoral fellowships from the National Institutes of Health and National Institute of Environmental Health and Safety under training grants T32-CA-09598 and T32-ES-07290.

\section{References}

1. Parrish JA, Fitzpatrick TB, Tanenbaum $L$ and Pathak MA (1974). Photochemotherapy of psoriasis with oral methoxalen and long wave ultraviolet light. N. Engl. J. Med. 291: 1207-1211

2. Haber LC (1974) Photochemotherapy of psoriasis. N. Engl. J. Med. 291: 1251 1252

3. Wolf K, Fitzpatrick TB and Parrish JA (1976) Photochemotherapy of psoriasis with oral 8-methoxypsoralen. Arch. Dermatol. 112: 934-950

4. Pathak MA, Fitzpatrick TB, Parrish JA and Biswas R (1977) In: Research in photobiology Castelani A, editor. (New York: Plenum Press) pp. 267-281

5. Dall'Acqua F (1977) New chemical aspects of photoreactions between psoralen and DNA. In: Research in photobiology, Castellani A, ed. Proceedings of the 7th International Congress on Photobiology, held in Rome, Italy, August 29 September 3, 1976. (New York: Plenum Press) p. 245-255

6. Song PS and Tapley Jr KJ (1979) Photochemistry and photobiology of psoralens. Photochem. Photobiol. 29: 1177-1197

7. Sage E and Bredberg A (1991) Damage distribution and mutation spectrum: the case of 8-methoxypsoralen plus UVA in mammalian cells. Mut. Res. 263: 217222

8. Ben-Hur E and Elkind MM (1973) DNA cross-linking in Chinese hamster cells exposed to near ultraviolet light in the presence of $4,5^{\prime}, 8$-trimethylpsoralen. Biochim. Biophys. Acta. 331: 181-193

9. Gunther EJ, Yeasky TM, Gasparro FP and Glazer PM (1995) Mutagenesis by 8methoxypsoralen and 5-methylangelicin photoadducts in mouse fibroblasts: mutations at cross-linkable sites induced by monoadducts as well as cross-links. Cancer Res. 55: 1283-1288

10. O'Neal MA and Griffin AC (1957) The effect of oxypsoralen upon ultraviolet carcinogenesis in albino mice. Cancer Res. 17: 911-916

11. Nataraj AJ, Black HS and Ananthaswamy HN (1996) Signature p53 mutation at DNA cross-linking sites in 8-methoxypsoralen and ultraviolet A (PUVA)-induced murine skin cancers. Proc. Natl. Acad. Sci. USA. 93: 7961-7965

12. Stern RS and Laird N (1994) The carcinogenic risk of treatments for severe psoriasis. Photochemotherapy Follow-up Study. Cancer 73: 2759-2764

13. Lindelof B, Sigurgeirsson B, Tegner E, Larko O, Johannesson A, Berne B, Ljunggren $B$, Andersson T, Molin L, Nylander-Lundqvist $E$ and Emtestam L. (1999)PUVA and cancer risk: the Swedish follow-up study. Brit. J. Dermatol. 141: $108-112$

14. Enomoto DN, Schellekens PT, Yong SL, ten Berge IJ, Mekkes JR and Bos JD (1997) Extracorporeal photochemotherapy (photopheresis) induces apoptosis in lymphocytes: a possible mechanism of action of PUVA therapy. Photochem. Photobiol. 65: 177-180

15. Johnson R, Staiano-Coico L, Austin L, Cardinale I, Nabeya-Tsukifuji R and Krueger JG (1996) PUVA treatment selectively induces a cell cycle block and subsequent apoptosis in human T-lymphocytes. Photochem. Photobiol. 63: $566-571$

16. Miracco C, RubegniP, De Aloe G, D’Ascenzo G, Mazzatenta C, De Santi MM and Fimiani M. (1997) Extracorporeal photochemotherapy induces apoptosis of infiltrating lymphoid cells in patients with mycosis fungoides in early stages. A quantitative histological study. Brit. J. Dermatol. 137: 549-557
17. Vowels BR, Yoo EK and Gasparro FP (1996) Kinetic analysis of apoptosis induction in human cell lines by UVA and 8-MOP. Photochem. Photobiol. 63: $572-576$

18. Yoo EK, Rook AH, Elenitsas R, Gasparro FP and Vowels BR (1996) Apoptosis induction of ultraviolet light $A$ and photochemotherapy in cutaneous T-cell Lymphoma: relevance to mechanism of therapeutic action. J. Invest. Dermatol. 107: $235-242$

19. Aringer M, Graninger WB, Smolen JS, Kiener HP, Steiner CW, Trautinger F and Knobler R. (1997) Photopheresis treatment enhances CD95 (fas) expression in circulating lymphocytes of patients with systemic sclerosis and induces apoptosis. Br. J. Rheumatol. 36: 1276-1282

20. Coven TR, Walters IB, Cardinale I and Krueger JG (1999) PUVA-induced lymphocyte apoptosis: mechanism of action in psoriasis. Photodermatol Photoimmunol Photomed. 15: 22-27

21. Iwasaki K, Izawa M and Mihara M (1996) UV-induced apoptosis in rat skin. J. Dermatol. Sci. 12: $31-35$

22. Cox LS and Lane DP (1995) Tumour suppressors, kinases and clamps: how p53 regulates the cell cycle in response to DNA damage. Bioessays 17: 501-508

23. Lane DP (1992) Cancer. P53, guardian of the genome [news; comment] [see comments]. Nature 358: $15-16$

24. Campbell C, Quinn AG, Angus B, Farr PM and Rees JL (1993) Wavelength specific patterns of p53 induction in human skin following exposure to UV irradiation. Cancer Res. 53: 2697-2699

25. Hall PA, McKee PH, Menage HD, Dover Rand Lane DP (1993) High levels of p53 protein in UV-irradiated normal human skin. Oncogene 8: 203-207

26. Zhan Q, Carrier F and Fornace Jr AJ (1993) Induction of cellular p53 activity by DNA-damaging agents and growth arrest [published erratum appears in Mol. Cell Biol. 1993 Sept; 13: 5928]. Mol. Cell. Biol. 13: $4242-4250$

27. Ko LJ and Prives C (1996) p53: puzzle and paradigm. Genes Dev. 10: 1054 1072

28. Kastan MB, Canman CE and Leonard CJ (1995) P53, cell cycle control and apoptosis: implications for cancer. Can. Met. Rev. 14: 3-15

29. El-Deiry WS, Tokino T, Velculescu VE, Levy DB, Parsons R, Trent JM, Lin D, Mercer WE, Kinzler KW and Vogelstein B. (1993) WAF1, a potential mediator of p53 tumor suppression. Cell 75: 817-825

30. Smith ML, Chen IT, Zhan Q, Bae I, Chen CY, Gilmer TM, Kastan MB, O'Connor PM and Fornace Jr AJ (1994) Interaction of the p53-regulated protein Gadd45 with proliferating cell nuclear antigen [see comments]. Science 266: 1376-1380

31. Bates $S$ and Vousden KH (1996) p53 in signaling checkpoint arrest or apoptosis. Curr. Opin. Genet. Dev. 6: 12-18

32. Strasser A, Harris AW, Jacks T and Cory S (1994) DNA damage can induce apoptosis in proliferating lymphoid cells via p53-independent mechanisms inhibitable by Bcl-2 [see comments]. Cell 79: 329-339

33. Gniadecki R, Hansen M and Wulf HC (1997) Two pathways for induction of apoptosis by ultraviolet radiation in cultured human keratinocytes. J. Invest. Dermatol. 109: 163-169

34. LiG, Mitchell DL, Ho VC, Reed JC and Tron VA (1996) Decreased DNA repair but normal apoptosis in ultraviolet-irradiated skin of p53-transgenic mice. Am. J. Path. 148: 1113-1123

35. Ziegler A, Jonason AS, Leffell DJ, Simon JA, Sharma HW, Kimmelman J Remington L, Jacks T and Brash DE. (1994) Sunburn and p53 in the onset of skin cancer. Nature 372: 773-776

36. Leverkus M, Yaar M and Gilchrest BA (1997) Fas/Fas ligand interaction contributes to UV-induced apoptosis in human keratinocytes. Exp. Cell Res. 232: $255-262$

37. Zhao JF, Zhang YJ, Kubilus J, Jin XH, Santella RM, Athar M, Wang ZY and Bickers DR. (1999) Reconstituted 3-dimensional human skin as a novel in vitro model for studies of carcinogenesis. Biochem. Biophys. Res. Comm. 254: 4953

38. Hannuksela-Svahn A, Paakko $P$, Autio $P$, Reunala $T$, Karvonen $\mathrm{J}$ and Vahakangas K (1999) Expression of p53 protein before and after PUVA treatment in psoriasis. Acta. Derm. Venereol. 79: 195-199

39. Kerr JF, Wyllie AH and Currie AR (1972) Apoptosis: a basic biological phenomenon with wide-ranging implications in tissue kinetics. Brit. J. Cancer 26: 239-257

40. Searle J, Lawson TA, Abbott PJ, Harmon B and Kerr JF (1975) An electronmicroscope study of the mode of cell death induced by cancer-chemotherapeutic agents in populations of proliferating normal and neoplastic cells. J. Pathol. 116: $129-138$ 
41. Cohen JJ (1993) Apoptosis. Immunol Today 14: 126-130

42. Thornberry NA and Lazebnik Y (1998) Caspases: Enemies within. Science 281 $1312-1316$

43. Molinari M, Okorokov AL and Milner J (1996) Interaction with damaged DNA induces selective proteolytic cleavage of p53 to yield $40 \mathrm{kDa}$ and $35 \mathrm{kDa}$ fragments competent for sequence-specific DNA binding. Oncogene 13: 2077 2086

44. Okorokov AL, Ponchel F and Milner J (1997) Induced N-and C-terminal cleavage of $p 53$ : a core fragment of $p 53$, generated by interaction with damaged DNA promotes cleavage of the $\mathrm{N}$-terminus of full-length $\mathrm{p} 53$, whereas ssDNA induces C-terminal cleavage of p53. EMBO J. 16: 6008-6017

45. Kubbutat MH and Vousden KH (1997) Proteolytic cleavage of human p53 by calpain: a potential regulator of protein stability. Mol. Cell. Biol. 17: 460-468

46. Macleod KF, Sherry N, Hannon G, Beach D, Tokino T, Kinzler K, Vogelstein B and Jacks T. (1995) p53-dependent and independent expression of p21 during cell growth, differentiation, and DNA damage. Genes Dev. 9: 935-944

47. Reed JC (2000) Mechanisms of apoptosis. Am. J. Pathol. 157: 1415-1430

48. Kroemer G (1999) Mitochondrial control of apoptosis: an overview. Biochem. Soc. Symp. 66: 1-15

49. Ouhtit A, Gorny A, Muller HK, Hill LL, Owen-Schaub L and Ananthaswamy HN (2000) Loss of fas-ligand expression in mouse keratinocytes during UV carcinogenesis. Am. J. Pathol. 157: 1975-1981

50. Hill LL, Ouhtit A, Loughlin SM, Kripke ML, Ananthaswamy HN and Owen-Schaub LB (1999) Fas ligand: a sensor for DNA damage critical in skin cancer etiology. Science 285: $898-900$

51. Haake AR and Polakowska RR (1993) Cell death by apoptosis in epiderma biology. J. Invest. Dermatol. 101: 107-112

52. Schindl A, Klosner G, Honigsmann H, Jori G, Calzavara-Pinton PC and Trautinger $F$ (1998) Flow cytometric quantification of UV-induced cell death in a human squamous cell carcinoma-derived cell line: dose and kinetic studies. J. Photochem. Photobiol. 44: 97-106

53. Takemori N and Hirai K (1995) [Significance of PUVA therapy for adult T-cell leukemia/lymphoma-PUVA therapy can induce apoptosis in leukemic cells] Hum. Cell. 8: 121-126

54. Yamaizumi M and Sugano T (1994) U.V.-induced nuclear accumulation of $p 53$ is evoked through DNA damage of actively transcribed genes independent of the cell cycle. Oncogene 9: 2775-2784

55. Fritsche M, Haessler C and Brandner G(1993) Induction of nuclear accumulation of the tumor-suppressor protein $\mathrm{p} 53$ by DNA-damaging agents [published erratum appears in Oncogene $1993 \mathrm{Sep} ; 8$ : 2605]. Oncogene 8: 307-318

56. Kleinau O, Bohm F and Lanto B (1997) Different DNA repair time courses in human lymphoid cells after UVA, UVA1, UVB and PUVA in vitro. J. Photochem. Photobiol. 41: 103-108

57. Ponten F, BerneB, Ren ZP, Nister Mand Ponten J (1995) Ultravioletlight induces expression of p53 and p21 in human skin: effect of sunscreen and constitutive p21 expression in skin appendages. J. Invest. Dermatol. 105: 402-406

58. Cooke MS, Finnegan MT, Herbert KE and Lunec J (1995) Cell cycle and dosedependence of DNA damage and p53 expression following UVA irradiation. Biochem. Soc. Trans. 23: 481S

59. Wang Y, Rosenstein B, Goldwyn S, Zhang X, Lebwohl M and Wei H (1998) Differential regulation of $\mathrm{P} 53$ and $\mathrm{Bcl}-2$ expression by ultraviolet $\mathrm{A}$ and $\mathrm{B}$. J. Invest. Dermatol. 111: 380-384

60. de Toledo SM, Azzam El, Keng P, Laffrenier S and Little JB (1998) Regulation of ionizing radiation of $\mathrm{CDC} 2$, cyclin $\mathrm{A}$, cyclin $\mathrm{B}$, thymidine kinase, topoisomerase Ilalpha, and RAD51 expression in normal human diploid fibroblasts is dependent on p53/p21Waf1. Cell Growth Differ. 9: 887-896
61. Liebermann DA, Hoffman B and Steinman RA (1995) Molecular controls of growth arrest and apoptosis: p53-dependent and independent pathways. Oncogene 11: $199-210$

62. Brown JM and Wouters BG (1999) Apoptosis, p53, and tumor cell sensitivity to anticancer agents. Cancer Res. 59: 1391-1399

63. Huang C, Ma WY, Li J, Hecht SS and Dong Z (1998) Essential role of p53 in phenethyl isothiocyanate-induced apoptosis. Cancer Res. 58: 4102-4106

64. Brash DE, Ziegler A, Jonason AS, Simon JA, Kunala S and Leffell DJ (1996) Sunlight and sunburn in human skin cancer: p53, apoptosis, and tumor promotion. J. Investig. Dermatol. Symp. Proc. 1: 136-142

65. Nagata S (1997) Apoptosis by death factor. Cell 88: 355-365

66. Griffith TS, Brunner T, Fletcher SM, Green DR and Ferguson TA (1995) Fas ligand-induced apoptosis as a mechanism of immune privilege. Science 270 : $1189-1192$

67. Boldin MP, Varfolomeev EE, Pancer Z, Mett IL, Camonis JH and Wallach D (1995) A novel protein that interacts with the death domain of Fas/APO1 contains a sequence motif related to the death domain. J. Biol. Chem. 270: 7795-7798

68. Chinnaiyan AM, O'Rourke K, Tewari M and Dixit VM (1995) FADD, a novel death domain-containing protein, interacts with the death domain of Fas and initiates apoptosis. Cell 81: 505-512

69. Chinnaiyan AM, Tepper CG, Seldin MF, O'Rourke K, Kischkel FC, Hellbardt S, Krammer PH, Peter ME and Dixit VM. (1996) FADD/MORT1 is a common mediator of CD95 (Fas/APO-1) and tumor necrosis factor receptor-induced apoptosis. J. Biol. Chem. 271: $4961-4965$

70. Owen-Schaub LB, Angelo LS, Radinsky R, Ware CF, Gesner TG and Bartos DP (1995) Soluble Fas/APO-1 in tumor cells: a potential regulator of apoptosis? Cancer Lett. 94: 1-8

71. Bennett M, Macdonald K, Chan SW, Luzio JP, Simari R and Weissberg P (1998) Cell surface trafficking of Fas: a rapid mechanism of p53-mediated apoptosis. Science 282: 290-293

72. TerakiY and Shiohara T(1999) Apoptosis and the skin. Eur. J. Dermatol. 9:413425

73. Denfeld RW, Hollenbaugh D, Fehrenbach A, Weiss JM, von Leoprechting A, Mai B, Voith U, Schopf E, Aruffo A and Simon JC. (1996) CD40 is functionally expressed on human keratinocytes. Eur. J. Immunol. 26: 2329-2334

74. Rosenstein BS and Mitchell DL (1987) Action spectra for the induction of pyrimidine (6-4) pyrimidone photoproducts and cyclobutane pyrimidine dimers in normal human skin fibroblasts. Photochem. Photobiol. 45: 775-780

75. Colburn NH, Bruegge WF, Bates JR, Gray RH, Rossen JD, Kelsey WH and Shimada T. (1978) Correlation of anchorage-independent growth with tumorigenicity of chemically transformed mouse epidermal cells. Cancer Res. 38: $624-634$

76. Mosmann T (1983) Rapid colorimetric assay for cellular growth and survival: application to proliferation and cytotoxicity assays. J. Immunol. Methods 65:5563

77. Wyllie AH and Morris RG (1982) Hormone-induced cell death. Purification and properties of thymocytes undergoing apoptosis after glucocorticoid treatment. Am. J. Pathol. 109: 78-87

78. Gurtu V, Kain SR and Zhang G (1997) Fluorometric and colorimetric detection of caspase activity associated with apoptosis. Anal. Biochem. 251: 98-102

79. Laemmli UK (1970) Cleavage of structural proteins during the assembly of the head of bacteriophage T4. Nature 227: 680-685

80. Bradford MM (1976) A rapid and sensitive method for the quantification of microgram quantities of protein utilizing the principle of protein-dye binding. Anal. Biochem. 72: 248-254 